\title{
CORRESPONDENCE
}

\section{Family planning}

GCSutton, MFCM

\section{Psychiatric illness among British}

Afro-Caribbeans

S P Sashidharan, MRCPSYCH.

\section{Pregnancy after renal transplantation}

S Niesert, MD, and others ..................... 1736

Iron and infection

D M J Barry, FRCP, and A W Reeve, FRACP ... 1736

Anorexia nervosa

T A Fahy, MB; D R Davies, Mrcrsych; A

Shah, MB, and D Baldwin, MB; K Matthews,

$\mathrm{MB}$, and J M Eagles, MRCPSYCH ............... 1736

\section{BRL 26830A and weight loss}

J F Munro, FRCP, and others; V M S Oh, MD,

and Elizabeth A Taylor, PHD .................. 1737

\section{Deaths from injury}

M D Bircher, FRCS; M W Beckett, MRCP ...... 1738

Treating claudication

D C Berridge, FRCSED, and others; P B S

Fowler, DM; M Gray, FRCS....

Care of physically handicapped young adults

R Hull, MRCP, and M Ann Hall, MRCP ......... 1739

Changes in social security benefits

C Finn, MRCPSYCH

Intravenous volume replacement

A da Silva, FRCSED; I D Anderson, FRCS ....... 1739

Penicillin allergy

H T Sørensen, MD ........................ 1739

Which patients should undergo laparoscopy?

A Woodward, FRCS, and others................ 1740

Respiratory illness and home environment

B E Marks, FRCGP ........................... 1740
Anticoagulation and stroke

$G$ Venables, MRCP......

Diagnosing Marfan's syndrome

Judith Savige............................. 1740

Points Frequency of attendance at anticoagulant clinics (A Kubie and others);

Health checks for older people (M G Brook);

Prevalence of urinary incontinence (P Britton and A C Dowell); Trends in mortality statistics (N Sawyer); Medical research (L M Franks); Delays in diagnosing and treating bladder cancer (B J Jenkins and others); Cough and angiotensin converting enzyme inhibition ( $\mathrm{R}$ C Brown and $\mathrm{C} W \mathrm{G}$ Turton); Travellers and preventive health care (M S B

Vaile); Induced ovulation in underweight women (S Gowers); Informed consent (P J Mahaffey).......

All letters must be typed with double spacing and signed by all authors.

No letter should be more than 400 words.

- For letters on scientific subjects we normally reserve our correspondence columns for those relating to issues discussed recently (within six weeks) in the BMF.

We do not routinely acknowledge letters. Please send a stamped addressed envelope if you would like an acknowledgment.

- Because we receive many more letters than we can publish we may shorten those we do print, particularly when we receive several on the same subject.

\section{Family planning}

SIR,-One hears so many tales of the closing down of family planning clinics (21 May, p 1474) that it is worth recording that in this district the converse is true. We cannot believe that we are exceptional.

Although this district faces considerable financial difficulties, which family planning cannot escape entirely, the managers have been supportive. They can afford this position because the professionals concerned have taken the lead in reviewing their efforts and developing new services by the creative use of existing resources.

The services available include a psychosexual counselling clinic-abolishing a long waiting list and a journey to the next district-a young people's advisory service in a deprived area with high rates of teenage pregnancy, and a cervical screening service which, from a "cold start" in February 1987, is on target to complete the call of all eligible women in 1989 . We are also pursuing effective low cost approaches to the control of human immunodeficiency virus infections.

One of the tests by which the introduction of general management must be judged is the extent to which it fosters a managerial, entrepreneurial climate in the health service. The family planning service can best defend its resources by a vigorous commitment to making the best use of them.

\section{G C Sutton}

Pontefract Health Authority,

West Yorkshire WF7 6HT

\section{Psychiatric illness among British Afro-Caribbeans}

SIR,-Drs Roland Littlewood and Maurice Lipsedge (2 April, p 950) point out the ethnocentric biases inherent in the practice of psychiatry in
Britain but unfortunately resurrect the myth that Afro-Caribbeans in Britain are more prone to schizophrenia than white people. They also assert that such an increased vulnerability is mediated through "experience of racism refracted through subtle cognitive changes, including selfhood, autonomy, and locus of control."

Epidemiological evidence appears to show that the risk of hospital admission for schizophrenia is raised among Afro-Caribbeans in the United Kingdom. The methodological deficiencies of these studies, however, make it difficult to estimate the magnitude of any relative risk, and the nature of psychiatric practice in relation to black people in Britain leads one to question whether hospital data could be relied on to estimate disease rates accurately. All of the studies referred to (except the unpublished Nottingham study) are based on secondary data for case definition, and, as the authors acknowledge, misdiagnosis of schizophrenia is likely to be more common in black patients. Most of the studies cited were conducted in inner city areas with substantial black populations, and the possibility that social drift had augmented the numerators cannot be ruled out. Almost a quarter of the admissions to this hospital, where McGovern and Cope carried out their study, ${ }^{1}$ come from outside the catchment area. Until ethnic variation in such inner city drift is clearly specified it would be contentious to accept that the numerator and denominator relate to the same population.

Even when such methodological problems are controlled for adequately we are left with a major source of bias. The referral routes and the status in mental institutions are different for AfroCaribbeans and the indigenous population. AfroCaribbeans are more likely to be admitted under coercion than whites, and it is possible that black people pass through the filters that exist between hospital and community more easily than white people. ${ }^{2}$ The authors admit that blacks are more likely to be given a diagnosis of schizophrenia in hospital settings than whites. This introduces a powerful bias in the calculation of population based rates. ${ }^{3+}$ Unless these problems are adequately dealt with it is premature to conclude that the incidence of schizophrenia is greater in blacks than whites.

The authors seem to be impatient to embrace a theory of increased vulnerability for mental illness among Afro-Caribbeans. Such theories have a long history in psychiatric literature. The vulnerability of blacks to mental illness has been understood previously in terms of their biology, culture, or a common experience (such as migration); but none of these has been sufficient to account for the increased risk of hospital admission and the greater risk that Afro-Caribbeans have of being diagnosed as suffering from schizophrenia.

The ideological underpinning of such an approach has been dealt with elsewhere, ${ }^{5}$ but the immediate problem is that the authors are shifting the focus of inquiry from the institutional and coercive nature of psychiatry as experienced by black people in this country to the study of black people themselves.

All Saints Hospital,

S P SASHIDHARAN Birmingham B18 5SD

1 McGovern D, Cope RV. The compulsory detention of males of different ethnic groups, with special reference to offende patients. Br F Psychiatry 1987;150:505-12.

2 Goldberg D, Huxley P. Mental illness in the communiv. The pathway to psychiatric care. London: Tavistock, 1980.

$3 \mathrm{Kraus}$ AS. The use of hospital data in studying the association hetwe a characteristic and a disease. Public Healh Rep 1954:69:1211:4

4 Masi AT. Potential uses and limitations of hospital data in epidemiological research. Am $f$ Public Health 1962;55:658-67. 5 Mercer K. Racism and transcultural psychiatry. In: Miller P, Rose N, eds. The powver of psychiatry. Cambridge: Polity Press,
1986.

\section{.} 741 